\title{
Criminal Threats against the Abuse of Bonded Zone Facilities
}

\section{Agus Widodo*) and Arpangi**)}

*) Student of Master of Law, Faculty of Law, Universitas Islam Sultan Agung Semarang, Indonesia, E-mail: dodovangomez@gmail.com

${ }^{* *}$ Faculty of Law, Universitas Islam Sultan Agung Semarang, Indonesia

\begin{abstract}
.
Bonded Zone is one form of facilities provided by the customs authority (Directorate General of Customs and Excise) to entrepreneurs in the form of a fiscal which aims to provide the maximum benefit for national economic growth as well as the usual form of treatment for international relations. Entrepreneurs using the Kawasan Beikat facility have the potential to abuse the facilities provided. This research is entitled Criminal Threats Against Misuse of Bonded Zone Facilities. The aim of this research is to find out whether the abuse of bonded zone facilities can be punished by crime and how the modes used by these 'naughty' businessmen are to divert or avoid import duties and taxes. The research method used is normative juridical. The conclusion of this research is that the entrepreneur who receives the facility can abuse the facility for the benefit of the entrepreneur or the interest of the individual so as to harm state revenue. Act No. 10 of 1995 concerning Customs in conjunction with Act No. 17 of 2006 concerning amendments to Act No. 10 of 1995 concerning Customs has regulated the criminal threats that can be imposed for the abuse of bonded zone facilities. The mode used is to reduce the actual / physical quantity of exported goods from the number of goods notified in the export document. It is as if the company has re-exported imported goods that have received facilities. But by them, not all of the imported goods are used for production / re-export but they are resold locally.
\end{abstract}

Keyword: Customs Facilities; Bonded Area; Smuggling Crime.

\section{Introduction}

The ASEAN Ecomonic Community (AEC) or better known as the ASEAN Economic Community was implemented in 2015. AEC has the characteristics of a single market and production base, where one of the elements is free flow of goods. The ASEAN region has now become a single and unified production-based market, where the mobility of the flow of goods, services, investment, capital and skilled labor will move freely between countries that are members of ASEAN countries in accordance with international standards and best-practices. Indonesia as a member of ASEAN has a high level of integrity in the electronics sector and a comparative advantage in natural resource-based sectors.

The tighter competition that the market will face for industrial products in Indonesia is the reason for the need for various efforts, both from the entrepreneurs themselves and from the government, to jointly increase the competitiveness of products made by domestic companies. One of the efforts to increase the competitiveness of domestic products is the provision of facilities that can support the investment climate by the government by providing facilities in the customs sector through the development and development of national strategic economic areas such as Bonded Zones. 
Bonded Zone is a Bonded Storage to store imported goods and / or goods originating from other places in the customs area to be processed or combined before being exported or imported for use. ${ }^{1}$ PMK Number 131 / PMK.04 / 2018 concerning Bonded Zone explains that the meaning of the Bonded Piling Place itself is a building, place, or area that meets certain requirements that are used to store goods for certain purposes by obtaining suspension of Import Duty.

Companies receiving Bonded Zone facilities get import duty postponement facilities, namely temporarily eliminating the obligation to pay import duties until the obligation to pay is issued based on law. This means that as long as the provisions that cause the import duty to be paid do not occur, the postponement of import duties remains in effect. If the company intends to release imported goods into the customs area (imported for use), an import duty will be levied, as long as the release is not directed to the party who has the import duty exemption or suspension facility.

The government hopes that as a Bonded Zone facility policy it can have a positive influence on domestic industry in particular and society in general, while from the entrepreneur's side, Bonded Zone facilities can increase the company's ability in product quality and quantity which in turn can increase company profits. Bonded Zones play a role as a support for the improvement of export-oriented industries, which are generally found in industrial areas and big cities. ${ }^{2}$

Several customs and taxation facilities obtained when an area is designated as a Bonded Zone raises public demands that the government can provide legal certainty in the business world, especially regulations regarding Bonded Zones. The government, particularly the Directorate General of Customs and Excise (DJBC), is tasked with securing government policies regarding the traffic of goods into and out of the customs area and the collection of import duties and excise and other state levies based on the prevailing laws and regulations.

In practice, Bonded Zone facilities can be misused. This will cause huge losses to the state. State revenue that should be acceptable to the State is used by "naughty" business parties to divert or avoid the obligation to pay Import Duty and Taxes.

Based on the aforementioned problems, the authors are interested in examining whether the abuse of bonded zone facilities can be punished by crime and how the mode used by these 'naughty' businessmen is to divert or avoid import duties and taxes.

\section{Research methods}

The approach method used in this legal research is normative juridical, where the law is conceptualized as what is written in statutory regulations (law in books) or law is conceptualized as a rule or norm which is a benchmark for human

\footnotetext{
${ }^{1}$ Article 1 explanation of Number 4 Regulation of the Minister of Finance Number 131 / PMK.04 / 2018 concerning Bonded Zones.

${ }^{2}$ Adhitama, Satria. Tinjauan Terhadap Pengawasan Pelaksanaan Subkontrak Barang Impor Dari Kawasan Berikat Ke Tempat Lain Dalam Daerah Pabean Dengan Jaminan Pada Wilayah Kerja KPPBC TMP A Bandung, Jurnal Perspektif Bea dan Cukai Vol. 3 No. 2 (2019) url: http://jurnal.pknstan.ac.id/index.php/PBC/article/view/552/346.
} 
behavior that is considered appropriate. ${ }^{3}$ The specification of this research is descriptive analysis, because in this study it describes the object that is the problem and then analyzed and drawn conclusions from the results of the study.

The type of data used is secondary data. This secondary data includes legal materials, as follows: 1) primary legal materials, 2) secondary legal materials, and 3) tertiary legal materials. Data processing and analysis methods are as follows, the data that has been obtained during the research by reading library books, journals, internet articles, then analyzed. The analysis used in this research is qualitative data analysis.

\section{Results and Discussion}

\subsection{Bonded Zone Facilities}

The rapid development of industry and trade raises public demands for the government to provide legal certainty in the business world. The government, especially the Directorate General of Customs and Excise (DJBC), which functions as trade facilitation, must be able to make a customs law that can anticipate developments in society in order to provide services and supervision that are faster, better, and cheaper. DGCE must do more to ensure legal certainty, fairness, transparency and accountability of public services, to support efforts to increase and develop the national economy related to global trade,

The government has issued Customs legislation number 10 of 1995 and has been revised by Act No. 17 of 2006. This law regulates customs services provided to the business world, such as: imports, exports, service facilities and facilities. fiscal. The definition of customs facilities is a form of special treatment in the process of resolving customs formalities in order to provide faster, better and cheaper services. its main purpose is to facilitate the flow of goods, people or documents. ${ }^{4}$ DGCE provides customs facilities with the hope of providing legal certainty as well as economic growth, while still paying attention to and being integrated with customs and taxation management, risk management, infrastructure, human resources and supervision systems.

The forms of customs facilities provided by the Customs Law can generally be divided into:

3.1.1. Service-related facilities, in order to provide faster, better and cheaper service. The form of service facilities is as follows:

- Unloading or Storage Outside the Customs Area

- Main Partner of Customs

- Authorized Economic Operator (AEO)

- Vooruistlag (Postponement of Import Duty Payment in Order

- Rush Handling (Releasing of Imported Goods for Immediate Service)

- Returnable Package

\footnotetext{
${ }^{3}$ Zainal Asikin and Amiruddin. (2012). Pengantar Metode Penelitian Hukum, Jakarta: Raja Grafindo Persada. p. 118.

4 Syaiful Anwar, November 17, 2014, "Mengenal Fasilitas Pabean dan Bea Masuk (Fasilitas Prosedural Kepabeanan)" http://www.bppk.kemenkeu.go.id/ accessed on November 30, 2020
} 
- Truck Loosing

- Pre-Entry Classification

- Periodic PIB

Customs facilities related to service / procedural services are provided to importers / exporters / transportation service entrepreneurs with the hope that they will take advantage of these facilities in order to reduce operating costs (handling costs), time efficiency and provide legal certainty.

3.1.2. Facilities related to fiscal, in the form of exemption, waiver, return and suspension of Import Duty.

Basically, the fiscal facility is a facility related to tax revenue, especially Import Duty. Fiscal facilities in the context of the Customs Law contain the meaning of tax incentives provided to industry, trade, and certain parties. The forms of customs fiscal facilities can be in the form of: Free Import Duty, Exemption from Import Duty, Exemption or Relief from Import Duty, Return of Import Duty; Exemption or Reduction of Import Duty in the context of Temporary Import, Postponement of Import Duty on bonded storage places.

The customs fiscal facility provided is aimed at providing the greatest possible benefit for national economic growth as well as the usual form of treatment for international relations. For the interests of industry and trade, the government provides incentives to industries that are building or developing. In connection with international relations, the government provides exemption treatment for imported goods to be used by representatives of foreign countries or officials in international agencies. Likewise, goods used for public interests that are not oriented towards commercial matters are given exemption from import duty.

Bonded zone is one type of bonded storage place which is granted import duty suspension and tax exemption facilities. Not all companies take advantage of this facility. Entrepreneurs who take advantage of this usually have international scale company activities that sell their products overseas and the materials are imported from abroad. Why is that? Because this entrepreneur, if he imports facilities, but his products are not sold abroad or are not transferred to other bonded storage places, then the sale / release of production goods and raw materials must pay Import Duty and Taxes in the framework of importing them. ${ }^{5}$

Entrepreneurs / companies that will get Bonded Zone facilities must meet the following terms and conditions: ${ }^{6}$

- already has a business identification number;

- has an industrial business license;

- has confirmation results of taxpayer status according to the application that shows valid;

- has proof of ownership or control of a place or building that has clear boundaries, along with a map of the location / place and a layout plan / floor plan; and

\footnotetext{
${ }^{5}$ Article 35 Regulation of the Director General of Customs and Excise Number: PER-19 / BC / 2018 concerning Bonded Zones.

${ }^{6}$ Article 9 Regulation of the Director General of Customs and Excise Number: PER-19 / BC / 2018 concerning Bonded Zones.
} 
- meet the criteria as Bonded Zone Entrepreneur or PDKB, namely:

- has been confirmed as a taxable entrepreneur and has submitted an annual income tax return for the last tax year in accordance with his / her obligations; and

- get a recommendation from the Bonded Zone Operator in the event that the company applies for a PDKB permit.

- $\quad$ The requirements are submitted to the Head of the Regional Officethrough ${ }^{7}$ the Head of the Customs Office ${ }^{8}$;

After the Entrepreneur / company obtains a decree stipulating as a bonded zone entrepreneur, the entrepreneur can carry out import activities by obtaining this facility. As long as the entrepreneur gets bonded zone facilities, the area / location where the entrepreneur's activities will be fully under the supervision of $\mathrm{DJBC}$, in this case the Customs Office will assign a Customs Officer to supervise and serve all activities of the entry and release of goods from and to the Bonded Zone. Every release and entry of goods must use customs notification documents ${ }^{9}$ and notified to the Customs and Excise Officer who supervises it.

\subsection{Criminal Threats Against Entrepreneurs Who Misuse Bonded Zone Facilities}

Bonded Zone facilities are needed by international scale entrepreneurs, both foreign investors and domestic entrepreneurs. The costs that they should use to pay Import Duty and Taxes can be transferred to other expenses. The existence of this facility does not mean that entrepreneurs can use them at will. There are strict sanctions in the form of administrative fines or criminal sanctions if they misuse bonded zone facilities.

Criminal action related to abuse of bonded zone facilities is one of the criminal acts in the customs sector. Customs crime is a special crime regulated in a law outside the Criminal Code. This particular crime is regulated in a law other than general criminal law. Deviations to the provisions of the criminal law contained in the criminal law law are an indicator of whether the criminal law is a special act or not, so it can be said that special criminal law is a criminal law or criminal law which is regulated in a separate criminal law. ${ }^{10}$

Principles according to the nature of criminal law as public law, the main objective of holding criminal law is to protect the interests of the community as a collectivity from actions that threaten or even harm them, whether they come from

\footnotetext{
${ }^{7}$ Regional Office or Main Service Office is the Regional Office or Main Service Office within the Directorate General of Customs and Excise where customs obligations are fulfilled in accordance with the Customs Law and the Excise Law.

8 The Customs Office is an office within the Directorate General of Customs and Excise where customs obligations are fulfilled in accordance with the Customs Law and the Excise Law.

${ }^{9}$ Customs Notification is a document or letter made by service users and submitted to the customs and excise office in carrying out customs obligations.

${ }^{10}$ Syamsuddin , Aziz. (2011). Tindak Pidana Khusus, (Editor) Tarmizi, Ed. 1. Cet.1, Jakarta: Sinar Grafika. p. 12.
} 
individuals or groups (organizations). Various social interests, among others, are peace, tranquility and orderliness of people's lives. ${ }^{11}$

Customs crime can also be said to be an economic crime. The conviction of economic crimes shall be adjusted to the imbalance which is disturbed and to the extent possible with the imposition of sanctions on the balance of economic life and the resulting state losses can be recovered. So the purpose of criminalization in the economic criminal law is to achieve a restoration of balance and development for the welfare of the people at large. ${ }^{12}$

We can see the criminal regulation in Article 102 letter $\mathrm{f}$ of the Customs Law, namely Act No. 10 of 1995 concerning Customs in conjunction with Act No. 17 of 2006 concerning amendments to Act No. 10 of 1995 concerning Customs.

Article 102

Anyone who:

- transporting imported goods that are not listed in the manifest as intended in Article 7A paragraph (2);

- unloads imported goods outside the customs area or other places without permission from the head of customs office;

- unloading imported goods that are not listed in the customs declaration as intended in Article 7A paragraph (3);

- unloading or storing imported goods that are still under customs control at a place other than the designated and / or permitted places of destination;

- hiding imported goods against the law;

- removing imported goods whose customs obligations have not been completed from the customs area or from a bonded storage place or from other places under customs control without the approval of the customs and excise officials, which results in non-fulfillment of state levies based on this Law;

- transporting imported goods from the temporary store or bonded store that does not arrive at the customs office of destination and cannot prove that it is beyond its capabilities; or

- intentionally notifying the type and / or quantity of imported goods in the customs declaration incorrectly, sentenced for smuggling in the import sector with a minimum imprisonment of 1 (one) year and a maximum imprisonment of 10 (ten) years and a minimum fine of Rp.50,000,000.00 (fifty million rupiah) and a maximum of Rp.5,000,000. 000.00 (five billion rupiah).

If seen from Article 102 above, this criminal threat is aimed at anyone who misuses the bonded zone facilities by removing imported goods from the bonded zone without the approval of the customs and excise officials and resulting in unfulfilled state levies. These violations include the crime of smuggling, which carries a criminal penalty of a minimum imprisonment of 1 year to a maximum of 10 years and a minimum fine of fifty million rupiah and a maximum of 5 billion rupiah.

\footnotetext{
11Jonaedi Efendi, and Ismu Gunadi W. (2011). Cepat \& Mudah Memahami Hukum Pidana(Jilid 1) Dilengkapi Buku l KUHP, Cetakan Pertama, Jakarta: PT. Prestasi Pustakaraya. p. 12.

12Syamsuddin, Aziz. Op.Cit, p. 12.
} 
The impact of not fulfilling state levies is in line with the impact of corruption which is detrimental to state finances. The real impact of corruption can be seen from the inhibition of growth in domestic investment and foreign investment needed in the development of the country's economy, the poor quality of public services, and limited infrastructure for the community, due to leaking of funds that should be used to maintain and improve. service for the community. ${ }^{13}$

If we look at the following chapters, we can find other articles that can be linked to article 102 above. Like Article 102B, adding its impact on the joints of the country's economy.

\section{Article 102B}

Violations as referred to in Article 102 and Article 102A which result in disruption of the joints of the country's economy are punished with imprisonment of at least 5 (five) years and imprisonment of up to 20 (twenty) years and a fine of at least IDR 5,000,000,000. 00 (five billion rupiah) and a maximum of IDR $100,000,000,000.00$ (one hundred billion rupiah).

Then, in Article $102 \mathrm{C}$ with the subject or the perpetrator being law enforcement officers, the punishment is increased by $1 / 3$.

\section{Article 102C}

In the case of a criminal act as stipulated in Article 102, Article 102A, Article 102B is committed by law enforcement officials and officials, the punishment imposed with punishment as the criminal threat in this Law is added by $1 / 3$ (one third).

Furthermore, in Article 104, this article threatens the parties who help transport or receive goods resulting from the crime.

\section{Article 104}

Anyone who:

- transport goods originating from the criminal act as meant in Article 102, Article 102A, or Article 102B;

- destroy, cut, hide, or dispose of books or records which according to this Law must be kept;

- eliminates, approves, or participates in removing information from customs declaration, complementary customs documents, or records; or

- keep and / or provide blank trade invoices from companies domiciled abroad which are known to be used as completeness of customs declarations according to this Law, shall be sentenced to imprisonment for a minimum of 1 (one) year, and a maximum imprisonment of 3 (three) years and / or a fine of at least Rp.500,000,000.00 (five hundred million rupiah) and a maximum of Rp.3,000,000,000.00 (three billion rupiah).

The Customs Law also has articles that threaten punishment for subjects in the form of legal entities, corporations and the like, namely in article 108.

\section{Article 108}

(1) In the event that a criminal act which is punishable under this Law is committed by or on behalf of a legal entity, company or company, association,

\footnotetext{
${ }^{13}$ Siregar, Hulman. Rumusan Pidana Dan Pemidanaan Tindak pidana Korupsi Yang Merugikan Keuangan Negara Serta Permasalaan Dalam Penerapannya, Jurnal Daulat Hukum Vol. 1 No. 1 (2018) url: http://jurnal.unissula.ac.id/index.php/RH/article/view/2626
} 
foundation or cooperative, criminal charges are addressed and criminal sanctions imposed on:

- the legal entity, company or company, association, foundation or cooperative concerned; and / or

- those who gave orders to commit the criminal act or who acted as leaders or who neglected to prevent it.

(2) Criminal acts according to this Law are also committed by or on behalf of legal entities, companies or companies, associations, foundations or cooperatives, if the criminal acts are committed by persons who are either based on a work relationship or based on other relationships acting in the environment. legal entity, company or company, association, foundation or cooperative regardless of whether the person is each has acted separately or collectively.

(3) In the event that a criminal charge is made against a legal entity, company or company, association, foundation or cooperative, the management who is represented at the time of the prosecution

the law can be held accountable according to the form of the legal entity concerned.

(4) With regard to legal entities, companies or companies, associations, foundations or cooperatives that are sentenced to the crimes referred to in this Law, the principal punishment imposed is always in the form of a maximum fine of Rp1,500,000,000.00 (one billion and five hundred. million rupiah) if the criminal act is punishable by imprisonment, without waiving the fine penalty if the criminal act is punishable by imprisonment and a fine.

If seen from the description above, the criminal threat given to abuse of bonded facilities can be aimed at individuals or corporations or legal entities. The articles that can be used are also in layers, according to the subject of the perpetrator and the resulting impact.

Abuse of bonded zone facilities in accordance with Article 102 of the Customs Law includes the crime of smuggling in the import sector.

The definition of smuggling (smuggling or Smokkle) according to Baharuddin Lopa is: "Importing, delivering goods that do not comply with the applicable laws and regulations, or do not meet the customs formalities (douaneformaliteiten) stipulated by the Legislation".14 Meanwhile, according to W.CO Hanbook for Comercial Fraud Investigators smuggling is importing or exporting outside the Customs and Excise domicile or importing / exporting at Customs and Excise domicile but by hiding the goods in concealment or on the passenger body. ${ }^{15}$

The definition of the crime of smuggling is: "Importing, exporting, delivering goods that do not comply with the prevailing laws and regulations or do not fulfill the customs formalities (douaneformaliteiten) which are applied by law. 16

In general, smuggling can be divided into two types, namely physical smuggling and administrative smuggling. Physical smuggling does not use

\footnotetext{
${ }^{14}$ Lopa , Baharudin. (2002). Tindak Pidana Ekonomi, Jakarta: PT. Pratnya Paramita. p. 29.

${ }^{15}$ World Customs Organization. (1997). WCO Hanbook for Comercial Fraud Investigators. Brussel;

${ }^{16}$ Chibro, Sofnir. (1992). Pengaruh Tindak Pidana Penyelundupan terhadap Pembangunan, Jakarta: Sinar Grafika, p. 5.
} 
documents at all, whereas in administrative smuggling there is a mismatch between the physical condition of the goods and what is written in the document. ${ }^{17}$

The crime of smuggling is as dangerous as the crime of corruption, in the sense that it is equally dangerous to state finances, which in turn will hinder development and will further complicate the road to the prosperity and welfare of the people.

The formulation of the smuggling criminal sanction as stipulated in the provisions of Article 102, Article 102 A, and Article 102 B of Act No. 17 of 2006 above basically applies criminal sanctions in the form of imprisonment and fines which are cumulative (combined) criminal sanctions., by prioritizing the application of imprisonment penalties first and then followed by cumulative fines. The formulation of the application of criminal sanctions like this shows that the perpetrator of the criminal act of smuggling is subject to quite severe double criminal sanctions, namely imprisonment on the one hand and at the same time being subject to a fine. However, if the fines cannot be paid with a subsidiary of Article 30 of the Criminal Code, it is very detrimental to the state.

The philosophical basis for the application of the smuggling criminal sanction is in the form of cumulative criminal sanctions, because the crime of smuggling is a form of "a crime or crime that harms the interests of state revenue, destroys the stability of the state economy or damages the joints of the state economy, and is detrimental to the potential for state revenue needed to finance it. national development in order to prosper the people at large ". Therefore, the perpetrators of the criminal act of smuggling need to be subject to alternative criminal sanctions so that the Customs Law is implemented and obeyed in order to increase the country's income and foreign exchange. If the criminal sanctions are not cumulatively formulated, the aspects of the interests of state financial revenue are not prioritized. ${ }^{18}$

The customs law does not explicitly regulate the concept of returning state losses as countries such as Singapore, Malaysia and China have succeeded in dealing with smuggling crimes because they have used and prioritized the concept of "return of state losses", therefore the government needs to reform Customs law, particularly regarding the formulation of criminal sanctions for the crime of smuggling, prioritizes and is based on the concept of "repayment of state losses" which is more beneficial to the interests of the Indonesian nation and state. ${ }^{19}$

Examples of cases of abuse of bonded zone facilities in Indonesia are rare. Our search results on the Internet, we found only 1 case that occurred which was quite large and excited among bonded zone entrepreneurs. The DJBC found that one of the textile companies located in the bonded area of Bandung, PT SPL, was abusing the facilities there some time ago. Instead of carrying out export activities,

\footnotetext{
${ }^{17}$ Syahputra, Azmi. Pertanggung Jawaban Pidana Terhadap Tindak Pidana Penyeludupan, Jurnal Ilmu Hukum Vol. 3 No. 1 url: https://media.neliti.com/media/publications/9136-ID-pertanggungjawaban-pidana-terhadap-tindak-pidana-penyeludupan.pdf

18 Wibowo, Yudi. (2013). Tindak Pidana Penyelundupan Di Indonesia, Jakarta: Sinar Grafika.

${ }^{19}$ Putu Kevin Saputra Ryadi, and Putu Kevin Saputra Ryadi. Pengaturan Sanksi Pidana Terhadap Pelaku Tindak Pidana Penyelundupan dalam Undang-Undang Kepabeanan, Jurnal Kertha Semaya, Vol. 4 No. 1 (2016) url: https://ojs.unud.ac.id/index.php/kerthasemaya/article/view/13400/9091
} 
the management of PT SPL has hoarded a number of goods that should have been sent abroad to be marketed in Indonesia secretly in order to avoid import duties and value added taxes. ${ }^{20}$

The mode used by the entrepreneur is by reducing the actual / physical quantity of exported goods from the number of goods notified in the export document. ${ }^{21}$ It is as if the company has re-exported imported goods that have received facilities. But by them, not all of the imported goods are used for production, but they are sold again locally. So, it is clear that the case above is very detrimental to state revenue. The businessmen should have paid import duties and taxes on the goods they smuggled.

The Customs and Excise investigator who handled the case above charged Article 103 letter a and / or Article 102 letter f of Act No. 17 of 2006 concerning Amendment to Act No. 10 of 1995 concerning Customs in conjunction with Article 55 of the Criminal Code in conjunction with Article 64 of the Criminal Code and Article 3 Act No. 8 of 2010 concerning the Crime of Money Laundering. ${ }^{22}$

\section{Closing}

Bonded Zone Facility is a facility provided by the customs authority (DJBC) in financial terms, namely suspension of import duty and tax exemption for import. In practice, dishonest entrepreneurs will be tempted to abuse these facilities. The Customs Law in article 102 threatens the abuse of bonded zone facilities with imprisonment and fines for being a smuggling crime.

The mode used by entrepreneurs is by reducing the physical / actual number of exported goods from the number of goods notified in their export documents. It is as if the company has re-exported imported goods that have received facilities. But by them, not all of the imported goods are used for production / re-export but they are resold locally. So, it is clear that the above case is very detrimental to state revenue. The businessmen should have paid import duties and taxes on the goods they smuggled.

Cases of abuse of bonded zone facilities are very rare. We suggest to the customs authorities to be more in-depth in overseeing the entrepreneurs who receive bonded zone facilities.

\section{References}

\section{Journals:}

[1] Adhitama, Satria. Tinjauan Terhadap Pengawasan Pelaksanaan Subkontrak Barang Impor Dari Kawasan Berikat Ke Tempat Lain Dalam Daerah Pabean Dengan Jaminan Pada Wilayah Kerja KPPBC TMP A Bandung, Jurnal

\footnotetext{
${ }^{20}$ Putera, Andri Donnal. November 2, 2017, "Terbongkar, Perusahaan Tekstil yang Selewengkan Fasilitas di Kawasan Berikat" https://ekonomi.kompas.com/read/2017/11/02/193958526/terbongkar-perusahaan-tekstilyang-selewengkan-fasilitas-di-kawasan-berikat, accessed on December 7, 2020.

21 Ibid.

22 Ibid.
} 
Perspektif Bea dan Cukai Vol. 3 No. 2 (2019) url: http://jurnal.pknstan.ac.id/index.php/PBC/article/view/552/346.

[2] Putu Kevin Saputra Ryadi, and Putu Kevin Saputra Ryadi. Pengaturan Sanksi Pidana Terhadap Pelaku Tindak Pidana Penyelundupan dalam UndangUndang Kepabeanan, Jurnal Kertha Semaya, Vol. 4 No. 1 (2016) url: https://ojs.unud.ac.id/index.php/kerthasemaya/article/view/13400/9091

[3] Siregar, Hulman. Rumusan Pidana Dan Pemidanaan Tindak pidana Korupsi Yang Merugikan Keuangan Negara Serta Permasalaan Dalam Penerapannya, Jurnal Daulat Hukum Vol. 1 No. 1 (2018) url: http://jurnal.unissula.ac.id/index.php/RH/article/view/2626

[4] Syahputra, Azmi. Pertanggung Jawaban Pidana Terhadap Tindak Pidana Penyeludupan, Jurnal Ilmu Hukum Vol. 3 No. 1 url: https://media.neliti.com/media/publications/9136-ID-pertanggungjawaban-pidana-terhadap-tindak-pidana-penyeludupan.pdf

\section{Books:}

[1] Chibro, Sofnir. (1992). Pengaruh Tindak Pidana Penyelundupan terhadap Pembangunan, Jakarta: Sinar Grafika.

[2] Jonaedi Efendi, and Ismu Gunadi W. (2011). Cepat \& Mudah Memahami Hukum Pidana(Jilid 1) Dilengkapi Buku l KUHP, Cetakan Pertama, Jakarta: PT. Prestasi Pustakaraya.

[3] Lopa, Baharudin. (2002). Tindak Pidana Ekonomi, Jakarta: PT. Pratnya Paramita.

[4] Syamsuddin , Aziz. (2011). Tindak Pidana Khusus, (Editor) Tarmizi, Ed. 1. Cet.1, Jakarta: Sinar Grafika.

[5] Wibowo, Yudi. (2013). Tindak Pidana Penyelundupan Di Indonesia, Jakarta: Sinar Grafika.

[6] World Customs Organization. (1997). WCO Hanbook for Comercial Fraud Investigators. Brussel;

[7] Zainal Asikin. and Amiruddin. (2012). Pengantar Metode Penelitian Hukum, Jakarta: Raja Grafindo Persada.

\section{Regulations:}

[1] Act No. 10 of 1995 concerning Customs.

[2] Act No. 17 of 2006 concerning Amendments to Law of the Republic of Indonesia No. 10 of 1995 concerning Customs.

[3] Minister of Finance Regulation Number 131 / PMK.04 / 2018 concerning Bonded Zones.

[4] Regulation of the Director General of Customs and Excise Number: PER-19 / BC / 2018 concerning Bonded Zones.

\section{Internet:}

[1] Anwar, Syaiful. November 17, 2014, "Mengenal Fasilitas Pabean dan Bea Masuk (Fasilitas Prosedural Kepabeanan)" http://www.bppk.kemenkeu.go.id/ accessed on November 30, 2020. 
[2] Putera, Andri Donnal. November 2, 2017, "Terbongkar, Perusahaan Tekstil yang Selewengkan Fasilitas di Kawasan Berikat" https://ekonomi.kompas.com/read/2017/11/02/193958526/terbongkarperusahaan-tekstil-yang-selewengkan-fasilitas-di-kawasan-berikat, accessed on December 7, 2020. 